\title{
Free Cash Flow and Investment Efficiency of Listed Manufacturing Companies in Nigeria
}

\author{
Aliyu Sulaiman Kantudu 1, Abubakar Sadiq Umar ${ }^{2}$ \\ ${ }^{1}$ Department of Accounting, Bayero University, Kano, Nigeria \\ ${ }^{2}$ Department of Accounting, Adamawa State University, Mubi, Nigeria \\ * Abubakar Sadiq Umar: sadiqtoungo@gmail.com
}

\author{
Article History \\ Received 2021-08-11 \\ Revised 2021-09-04 \\ Revised 2021-10-03 \\ Accepted 2021-10--03 \\ Published 2021-10-06

\section{Keywords} \\ Free cash flow \\ Investment efficiency \\ Overinvestment \\ Underinvestment \\ Agency cost

\section{How to cite?} \\ Kantudu, A. S., \& Umar, A. S. (2021). \\ Free Cash Flow and Investment Efficiency \\ of Listed Manufacturing Companies in \\ Nigeria. SEISENSE Journal of \\ Management, 4(4), 77-88. doi: \\ 10.33215/sjom.24i4.698 \\ Copyright (C) 2021 The Author(s) \\ (cc) BY
}

Purpose- This study aims to determine the relationship between free cash flow and investment efficiency of quoted manufacturing companies in Nigeria.

Design- An accounting-based model developed by Richardson (2006) was employed to measure investment efficiency and free cash flow. The population of the study consist of all the listed manufacturing companies in Nigeria. Similarly, the purposive sampling technique was employed to arrive at forty-eight companies for 2008-2018.

Findings- The results of the study confirm the agency theory of free cash flow. Hence, it established that there is a positive and robust relationship between free cash flow and overinvestment.

Practical Implications- the findings of this study has practical implications to various group of users of financial information such as investors, policymakers and other stakeholders in the listed manufacturing sector in Nigeria. The study recommends that policymakers reduce the cost of debt, and likewise, managers should emphasize the facilitation of equity capital.

Originality- To the best of the researcher's knowledge, this is the first study to examine the relationship between free cash flow and investment efficiency in Nigeria. 


\section{Introduction}

The finance literature has debated heavily on the issue of investment inefficiencies. Researchers have advanced many reasons as to the cause of inefficient investment, which manifests itself in the form of over-orunderinvestment that can damage the interest of shareholders. Firms invest efficiently in a perfect market when they undertake all the investments that will result in positive net present value projects and discard those investments that will lead to harmful net present value projects. Though previous studies (e.g., Angela \& Rilya, 2017; Chen, Hope, Li, \& Wang, 2011; Cherkasova \& Rasadi, 2017; Fakhroni et al., 2018; Guariglia \& Yang, 2016; Nekhili, Fakhfakh, Amar, Chtioui, \& Lakhal, 2016) suggest otherwise, this is as a result of the presence of market frictions. Thus, market frictions resulting in a clash of interest between shareholders, managers, and other stakeholders leads to agency conflict and asymmetric information. This clash of interest ultimately leads to passing up investment opportunities with a positive net present value outcome (underinvestment) and accepting projects that yield negative net present value outcomes (overinvestment), thus harming the interest of shareholders. Therefore, agency theory states that excess cash at the management's disposal after exhausting all expected investments provides a significant chance for the manager's abnormal behavior (Jensen \& Meckling, 1976).

However, despite the significance of investment, most of the extant studies were carried out in advanced economies with little empirical evidence in emerging economies, even though emerging economies make up a more significant proportion of the economic activities in the world ( $\mathrm{Rad}$ et al. 2016). More so is the fact that the problems of agency conflicts are more pronounced in emerging markets because of its capital market imperfections and its weak corporate governance structures. Thus, the relationship between free cash flow (henceforth FCF) and investment efficiency (IE) remains unclear in an African context. Hence, findings from advanced countries may not sustain the prediction of agency theory from an African economy such as Nigeria. For this reason, this study investigates the extent to which FCF impacts IE in the listed manufacturing sector in Nigeria from 2008-2018. Consequently, this study extends the field of application of FCF on IE in the listed manufacturing companies in Nigeria.

The motivation for this study is threefold; first, prior literature focused majorly on developed economies with little emphasis on emerging economies. Second, despite the minor focus on emerging economies, most studies focused on Asian and South American economies with significant African economies. Third, Nigeria is the hub of the African economy, with the largest economy in Africa (Umoru and Nwokoye 2018). As such, it will be the ideal country to examine in the African context. The manufacturing sector is one of the most critical sectors that bring about rapid industrialization and economic growth in any country in the world over (Ogunleye et al. 2018). Generally, the development of the industrial sector has been an essential component in the fruitful change of many powerful nations' states that have witnessed continued increases in revenues (Soderbom and Teal 2002). The sector is presumed to be a significant and robust determinant of growth, can reduce the poverty rate, and brings about sustainable development in an economy. The manufacturing industry is perceived as a standard for assessing a nation-states' economic progress and advancement. In light of this, the significance of the manufacturing sector's contributions to the growth of an economy cannot be over-stressed. However, despite this significance, the Nigerian manufacturing sector has fared poorly due to the over-reliance on crude oil, inadequate infrastructures, shortage of skilled labor, and inadequate financial resources (Ku, Mustapha, and Goh 2010).

The manufacturing sector can complement Nigerian government efforts at boosting local investment and making significant contributions to the nation's economic growth and development. Hence, efficient investment would have been the key; since investment is seen to prevent backwardness and recession (Jafari 2016). Consequently, Nigeria needs to emphasize firm-level investment, thereby ensuring an efficient 
investment of its resources. Similarly, the growth of the capital market in Nigeria creates new opportunities for stakeholders and, at the same time, exposes managers to a large pool of FCF, shareholders, and creditors. Such exposure calls for stricter regulations and places more restrictions on the management's decision-making processes.

The remainder of the paper is organized thus: Section two reviews related literature and develops the hypotheses. Section three presents the sample and the methodology. Section four displays the main empirical results, and Section five concludes.

\section{Literature Review and Hypotheses Development}

The concept of IE is well established in the literature of finance (Biddle et al., 2009; Chen et al., 2011; Cherkasova \& Rasadi, 2017; Gao \& Yu, 2018; Guariglia \& Yang, 2016; Majeed et al., 2017; Mcdermott, 2012; McNichols \& Stubben, 2008; Moez \& Amina, 2018; Nekhili, Fakhfakh, Tawhid, et al., 2016; Richardson, 2006; Verdi, 2006). Researchers all over the globe have given a divergent opinion on IE. For example, Majeed, Zhang, \& Muhammad (2017) view IE as the required size of investment expenditure, calculated as the level of projected investment based on an increased sales level. Positive deviation from the predicted level is considered overinvestment, that is, investment higher than expected level. Also, negative deviance from the predicted level is regarded as underinvestment; investment is lower than expected. This research follows the definition of Biddle \& Hilary (2006); Mcdermott (2012) that conceptually define investment efficiency as those firms that undertake projects that have positive net present value (NPV). Moreover, underinvestment or low investment refers to not taking investment opportunities that would yield a positive NPV. At the same time, overinvestment or excess investment refers to engaging in investment with a negative NPV. Consequently, both underinvestment and overinvestment are regarded as inefficient investments.

There is no association between a company's investments and its FCF (Modigliani and Miller 1958). Nonetheless, several studies have shown a positive relationship between investment inefficiency and FCF. Richardson (2006) study in the USA reveals that firms overinvest $20 \%$ of their excess FCF. Two possible scenarios may be the reasons for this association; the first is asymmetric information, and the second is agency costs. Asymmetric information among lenders, investors, and managers may affect investment decisions, resulting in inefficient investment. For instance, because of asymmetric information, managers tend to have superior information than outside capital providers regarding the actual development of the firm, possibly leading to a situation by which outside capital providers cannot make optimal investment decisions (Lai, Liu, and Wang 2013). Because of the information at the managers' discretion, they may be inclined to issue capital when the company is high-priced or issue costly capital to stakeholders since they have more information about the companies actual worth (Firth, Xie, and Zhang 2016).

Consequently, if managers can raise funds through this means, they will have excess funds, resulting in overinvesting such funds. This situation will enable managers to invest in unnecessary projects, thus overinvesting such funds rather than returning them to the owners (Chen, 2017). Conversely, because of inadequate information at their disposal, lenders may sense such opportunistic behaviors by managers and react by raising the firm's cost of debt (Lai et al., 2013). This situation can affect every company, including the ones that do not overvalue their shares prices. Therefore, because they will opt to protect existing shareholders, they will be forced to forfeit outstanding investment ventures rather than sell their shares below their actual worth. In turn, they may have to resort to internal funds for their investment projects (Cherkasova and Zakharova 2016). This situation could lead to financial constraints. Firms that are financially constrained tend to underinvest when the cost of raising external funds is high. This constrain is due to the capital market imperfections, leading to the high cost of debt. The cost of raising outside finance forces companies to source funds internally. In these situations, firms with inadequate funds may have to waive profitable investment 
opportunities because of the high debt associated with external funding (Guariglia and Yang 2016). Therefore, firms with a lack of adequate finance are more prone to underinvest (Li, Monroe, and Coulton 2018). Thus, the high sensitivity of underinvestment to FCF might be perceived as evidence of negative cash flow. Hence, resulting in underinvestment because of the high cost of external financing and the over-reliance of firms on internal funds.

The second reason is the agency cost. The separation of ownership and control brings about agency costs, thereby facilitating overinvestment. Managers in firms with excess FCF have an excellent reason to overinvest such funds (Jensen, 1986). Because of the separation of ownership and control that leads to agency cost, management may invest in projects for selfish reasons, which are helpful from the management viewpoint but may not be suitable for the owners of the company (Chen et al., 2016). The agency cost explanation is more so for companies with excess FCF. The agency cost problem of FCF is a problem between management and shareholders of the firm related to the company's usage of its excess FCF (Fakhroni et al. 2018). The clash of interests between the management and the outsider could lead managers to expropriation by utilizing the firm's FCF (Jensen, 1986). The insiders can exert control of the firms' resources than outsiders and have more information. Managers' quest to expand their power through control over more significant resources has increased their desire to enlarge the firm beyond its capacity (Jensen, 1986). It is hence overinvesting the firms' resources.

Therefore, the availability of excess FCF will provide a more significant opportunity for managers' dysfunctional behavior. The discussion so far has given rise to the agency problem of FCF. FCF refers to excess cash to be distributed to shareholders as dividends. Economic experts contend that a percentage of cash flows from operating activities should be given as dividends to shareholders and not only be financed in new investment projects only as the case may be (Bhundia 2012). However, conflicts of interest among stakeholders in the firm may cause the FCF not to be given to the shareholders, subsequently leading to an agency problem of FCF. Jensen (1986) contends that giving dividends creates one of the main problems among stakeholders because it decreases the number of funds under the control of the management, thereby lessening their influence. The decrease of funds in the manager's custody makes it more likely to monitor the capital market because of the firm's need to get new funds. Funding investment projects internally avoid this monitoring cost. Another issue advanced by Jensen (1986) is that insiders have the motivation to cause the company to grow more than its average scope. Such growth increases the manager's powers since it increases the resources under their management, increasing their remuneration.

From the discussion above, it can be inferred that investment inefficiency centers on the availability of free cash and its utilization. Hence, firms with excess cash may engage in overinvestment, and likewise, firms with inadequate free cash may engage in underinvestment.

Based on the preceding, the following hypotheses are formulated as follows:

H1: Free cash flows are negatively associated with investment efficiency in the listed manufacturing companies in Nigeria.

$\mathrm{H} 2$ : Free cash flows have no significant influence on overinvestment in the listed manufacturing companies in Nigeria.

H3: Free cash flows do not influence underinvestment in the listed manufacturing companies in Nigeria.

\section{Methodology}

The research design for this study is explanatory. At the same time, the population consists of all the sixty manufacturing companies quoted on the first-tier securities market of the Nigerian Stock Exchange (NSE) as of 31st December 2018. A purposive sampling technique was used for this research. An accounting-based 
model developed by Richardson (2006) was employed to measure IE. The model has been used severally by prior research in this area (Chen et al., 2011; Cherkasova \& Rasadi, 2017; Moez \& Amina, 2018). The model predicts the firm's IE, and the model's residuals were used as a proxy for inefficient investment. The residual from the model was used to measure investment inefficiency as deviations from normal investment, which is a function of growth opportunities. The positive deviations from the expected investment are termed overinvestment, while negative deviations from the normal investment are termed underinvestment. Consequently, both overinvestment and underinvestment are termed inefficient investments. The model is described below:

Investment $_{\mathrm{it}}=\beta_{0}+\beta_{1}$ Growth $_{\mathrm{i}, \mathrm{t}-1}+\beta_{2}$ Leverage $_{\mathrm{i}, \mathrm{t}-1}+\beta_{3}$ Cash $_{\mathrm{i}, \mathrm{t}-1}+\beta_{4}$ Size $_{\mathrm{i}, \mathrm{t}-1}+\beta_{5}$ Return $_{\mathrm{i}, \mathrm{t}-1}+\beta_{6}$ Age $_{\mathrm{i}, \mathrm{t}-1}+$ $\beta_{7}$ Investment $_{\mathrm{i}, \mathrm{t}-1}+\varepsilon_{\mathrm{it} .}$

Where; Investment $\mathrm{it}_{\mathrm{it}}$ is the totality of research and development expenditures, capital expenses and acquisitions minus sales of property, plant, and equipment (PPE), scaled by lagged total asset for the company $i$ at the end of year $\mathrm{t}-1$.

Growth $_{\mathrm{i}, \mathrm{t}-1}$; is the yearly income growth percentage for the company $i$ at the end of year $\mathrm{t}-1 \beta_{2}$

Leverage $_{i, t-1}$; is the financial leverage of the firm, is calculated as the ratio of non-current debt to the sum of non-current debt plus the current stock price multiplied by the number of shares outstanding of firm $i$ at the end of year $t-1, \beta_{3}$

Cash $_{\mathrm{i}, \mathrm{t}-1}$; is the proportion of cash to the total asset of firm $\mathrm{i}$ at the end of year $\mathrm{t}-1$

$\beta_{4} \operatorname{Size}_{i, t-1}$; is the logarithm of total assets of firm $i$ at the end of year $t-1$

$\beta_{5} \operatorname{Return}_{\mathrm{i}, \mathrm{t}-\mathrm{i}}$; is the change in market value over that of the prior year

$\beta_{6}$ Age $_{i, t-1}$; is the difference between the number of years the firm has been in existence and at the end of year $\mathrm{t}-$ 1

$\beta_{7}$ Investment $_{i, t-1}$; is the lag of investment or previous investment

The independent variable used in this study is FCF. An accounting-based model developed by Richardson (2006) was utilized in measuring FCF. Several researchers have applied the model in their research (Chen et al., 2016; Fusheng et al., 2015; Moez \& Amina, 2018). FCF is cash flow more than required to maintain assets in place, including maintaining existing debt and funding normal optimal new investments (Richardson 2006). Estimates of three constituents were utilized in measuring FCF;

An estimate of cash flow from assets in place ( $\left.\mathrm{CF}_{\mathrm{AIP}}\right)$.

An estimate of investment expenditure essential to sustain assets in place (I $\left.\mathrm{I}_{\text {MAINTENANCE}}\right)$.

An estimate of the normal level of new investment expenditure $\left(\mathrm{I}_{\mathrm{NEW}}\right)$.

Thus, to ascertain cash flow from assets in place, $\mathrm{CF}_{\text {AIP }}$;

$\mathrm{CF}_{\mathrm{AIP}}=\mathrm{CFO}-\mathrm{I}_{\text {MAINTENANCE }}+\mathrm{RD}$

Finally, to calculate FCF, the following is applied:

$\mathrm{FCF}=\mathrm{CF}_{\mathrm{AIP}}-\mathrm{I}^{*} \mathrm{NEW}$.

Note: expected new investment (I* NEw) is the absolute residual of the investment model defined above. 
Consistent with Moez \& Amina (2018), the FCFs obtained above were scaled by the total assets' book value to control the size effect.

Motivated by prior studies, several control variables were included in this study used in prior research as determinants of investment decisions (e.g., Chen et al., 2011; Cherkasova \& Rasadi, 2017; Fusheng et al., 2015; Richardson, 2006). These control variables include; size, firm age, the level of cash, leverage, growth, cash flow from operations, tangibility, slack, past stock, lagged investment, and returns. These variables are explained in the table below.

Table 1: Control Variable Definition and Its Measurement

\begin{tabular}{|c|c|c|}
\hline Variable & Definition & Measurement \\
\hline Growth $_{\mathrm{i}, \mathrm{-}-1}$ & Growth opportunity & $\begin{array}{l}\text { proportional change in income from year } \mathrm{t}-2 \text { to } \mathrm{t}-1 \text { (see, } \\
\text { Cherkasova \& Rasadi, 2017; Moez \& Amina, 2018) }\end{array}$ \\
\hline Leverage $_{i, t-1}$ & Financial leverage & $\begin{array}{l}\text { The proportion of the amount of the book value total debt } \\
\text { to total assets for firm i at the end of year t-1(see Biddle et } \\
\text { al., 2009; Moez \& Amina, 2018) }\end{array}$ \\
\hline $\operatorname{Cash}_{\mathrm{i}, \mathrm{t}-1}$ & Level of liquidity & $\begin{array}{l}\text { The proportion of cash to the total asset of firm } i \text { at the end } \\
\text { of year t-1 (see, Cherkasova \& Rasadi, 2017) }\end{array}$ \\
\hline Size $_{i, t-1}$ & Firm size & $\begin{array}{l}\text { Log of total assets of firm } i \text { at the end of year t-1(see, Moez } \\
\text { \& Amina, 2018) }\end{array}$ \\
\hline $\operatorname{Return}_{\mathrm{i}, \mathrm{t}-1}$ & Stock returns & $\begin{array}{l}\text { Stock returns of firm i at the end of year t-1 (see Wang et al. } \\
\text { 2015) }\end{array}$ \\
\hline $\operatorname{Age}_{i, t-1}$ & $\begin{array}{l}\text { Age of the firm is the number } \\
\text { of years the firm has been in } \\
\text { existence }\end{array}$ & $\begin{array}{l}\text { This is the difference between the first year of incorporation } \\
\text { of firm i and year } 2018 \text { for firm I at the end of year t- } 1 \text { (see } \\
\text { Wang et al. 2015) }\end{array}$ \\
\hline Tangibility & Tangible assets & $\begin{array}{l}\text { This is the proportion of property plant and equipment to } \\
\text { total assets (Biddle et al. 2009) }\end{array}$ \\
\hline $\begin{array}{l}\text { Lagged } \\
\text { investment }\end{array}$ & prior firm-level investment & $\begin{array}{l}\text { (Cherkasova and Rasadi 2017; Moez and Amina 2018; } \\
\text { Richardson 2006) }\end{array}$ \\
\hline $\mathrm{CFO}$ & cash flow from operations & $\begin{array}{l}\text { This is the ratio of cash flow from operations to sales } \\
\text { (Biddle and Hilary 2006; Verdi 2006) }\end{array}$ \\
\hline Slack & Slack & $\begin{array}{l}\text { This is the proportion of cash to property plant and } \\
\text { equipment (Chen et al. 2011; Verdi 2006) }\end{array}$ \\
\hline
\end{tabular}

Source: Extracted and summarized by the researcher from previous studies

The following regression model was utilised in assessing the effect of FCF on IE.

$I^{*}$ new $_{\mathrm{i}, \mathrm{t}}=\beta_{\mathrm{o}}+\beta_{2} \mathrm{FCF}_{\mathrm{I}, \mathrm{t}-1}+\beta_{4} \mathrm{Grwt}_{\mathrm{i}, \mathrm{t}-1}+\beta_{5} \mathrm{Lev}_{\mathrm{I}, \mathrm{t}-1}+\beta_{6} \operatorname{Cash}_{\mathrm{I}, \mathrm{t}-1}+\beta_{7} \operatorname{Size}_{\mathrm{I}, \mathrm{t}-1}+\beta_{8} \operatorname{Ret}_{\mathrm{I}, \mathrm{t}-1}+\beta_{9} \operatorname{Age}_{\mathrm{I}, \mathrm{t}-1}+\beta_{10} \operatorname{Tan}_{\mathrm{i}, \mathrm{t}-\mathrm{1}}+$ $\beta_{11} \operatorname{Inv}_{\mathrm{i}, \mathrm{t}-1}+\beta_{12} \mathrm{CFO}_{\mathrm{it}}+\beta_{13} \operatorname{Slack}_{\mathrm{I}, \mathrm{t}-1}+\varepsilon_{\mathrm{it} .}$.

Where:

$I^{*}$ new $=$ Investment Efficiency

$\mathrm{FCF}=$ Free cash flow

Grwt $=$ Growth

Lev $=$ Leverage 
Ret $=$ Stock returns

Tan $=$ Tangibility

Inv $=$ Lagged investment

$\mathrm{CFO}=$ cash flow from operations

$\mathrm{I}^{\mathrm{E}}$ new $_{\mathrm{i}, \mathrm{t}}=\beta_{\mathrm{o}}+\beta_{2} \mathrm{FCF}_{\mathrm{I}, \mathrm{t}-1}+\beta_{4} \mathrm{Grwt}_{\mathrm{i}, \mathrm{t}-1}+\beta_{5} \mathrm{Lev}_{\mathrm{I}, \mathrm{t}-1}+\beta_{6} \operatorname{Cash}_{\mathrm{I}, \mathrm{t}-1}+\beta_{8} \operatorname{Ret}_{\mathrm{I}, \mathrm{t}-1}+\beta_{9} \operatorname{Age}_{\mathrm{I}, \mathrm{t}-1}+\beta_{10} \operatorname{Tan}_{\mathrm{i}, \mathrm{t}-1}+\beta_{12} \mathrm{CFO}_{\mathrm{it}}+$ $\beta_{13}$ Slack $_{\mathrm{I}, \mathrm{t}-1}+\varepsilon_{\text {it.. }}$

Where:

$\mathrm{I}^{\mathrm{E}}$ new $=$ Overinvestment, the rest of the variable is as defined in equation (iii)

$\mathrm{I}^{\mathrm{E}}$ new $_{\mathrm{i}, \mathrm{t}}=\beta_{\mathrm{o}}+\beta_{2} \mathrm{FRQ}_{\mathrm{I}, \mathrm{t}-1}+\beta_{4} \mathrm{Grwt}_{\mathrm{i}, \mathrm{t}-1}+\beta_{5} \operatorname{Lev}_{\mathrm{I}, \mathrm{t}-1}+\beta_{6} \operatorname{Cash}_{\mathrm{I}, \mathrm{t}-1}+\beta_{7} \operatorname{Size}_{\mathrm{I}, \mathrm{t}-1}+\beta_{8} \operatorname{Ret}_{\mathrm{I}, \mathrm{t}-1}+\beta_{10} \operatorname{Tan}_{\mathrm{i}, \mathrm{t}-1}+\beta_{11} \operatorname{Inv}_{\mathrm{i}, \mathrm{t}-1}+$ $\beta_{12} \mathrm{CFO}_{\mathrm{it}}+\beta_{13} \mathrm{Slack}_{\mathrm{I}, \mathrm{t}-1}+\varepsilon_{\mathrm{it} .}$

Where:

$\mathrm{I}^{\mathrm{E}}$ new $=$ Underinvestment, the rest of definition of the variable name is same as equation (iii)

\section{Results and Discussion}

Table 2: Descriptive Statistics

\begin{tabular}{lccccc}
\hline Variables & OBS & Mean & STD & Min & Max \\
\hline InvEff & 528 & 0.0535 & 0.0206 & 0.0065 & 0.0959 \\
OverInv & 222 & 0.0694 & 0.0770 & 0.0000 & 0.3876 \\
UnderInv & 306 & 0.0504 & 0.2218 & -0.1262 & 3.8112 \\
FCF & 528 & -0.0163 & 0.1610 & -1.4826 & 1.4247 \\
Grwt & 528 & 0.0695 & 0.2256 & -0.3901 & 0.5330 \\
Lev & 528 & 0.5403 & 0.3710 & 0.0000 & 3.7225 \\
Cash & 528 & 0.1004 & 0.1810 & 0.0000 & 1.3431 \\
Size & 528 & 9.0504 & 2.9632 & 0.0000 & 12.207 \\
Return & 528 & 0.0174 & 0.3614 & -0.8894 & 0.7565 \\
Age & 528 & 39.659 & 22.696 & 0.0000 & 94.000 \\
Lag Inv & 528 & 0.0477 & 0.0315 & -0.3490 & 0.1662 \\
Tan & 528 & 0.3936 & 0.2559 & 0.0000 & 1.1899 \\
CFOS & 528 & 0.1153 & 0.1859 & -0.3261 & 0.5435 \\
Slack & 528 & 0.2322 & 0.2857 & 0.0000 & 1.6898 \\
\hline
\end{tabular}

Source: Computed by the Researcher using STATA16

Table 2 presents the descriptive statistics for investment efficiency consisting of 528 firm-year observations from 2008-2018. The mean value of investment efficiency for Nigeria's sampled listed manufacturing companies reveals an average value of about 0.054 . This means that listed manufacturing companies in Nigeria invest efficiently, on average, about $5.4 \%$ of their assets. The average value of 0.054 is lower than the result of (Cherkasova and Rasadi 2017), which is 0.07 and also lower than the average value of (Moez and Amina 2018) of 0.09 as well as $13.1 \%$ of (Richardson 2006). This clearly shows that the advanced countries have a higher level of investment efficiency than emerging economies, as evidenced by the result of (Moez and Amina 2018; Richardson 2006).

The descriptive statistics for overinvesting firms in the listed manufacturing sector consist of 222 firm-year observations. The mean value of overinvestment for Nigeria's sampled listed manufacturing companies reveals 
an average value of about 0.069 . This shows that listed manufacturing companies in Nigeria overinvest, on average, about $6.9 \%$ of their assets. The average value of 0.069 is lower than the result reported by (Wang et al. 2015), which is 0.085 and the result reported by (Cherkasova and Rasadi 2017) of 0.071, but higher than the average value of (Moez and Amina 2018) of $0 \%$. This shows that there is a variation in the level of overinvestment in emerging economies. Nonetheless, the results reveal that overinvestment in emerging economies such as China and Eastern Europe is higher than that of Nigeria. However, advanced countries such as the US have lower overinvestment problems (with up to $0 \%$ overinvestment), as documented in previous studies such as Moez and Amina (2018); Richardson (2006).

The descriptive statistics for underinvesting firms in the listed manufacturing sector comprise 306 firm-year observations from 2008-2018. The mean value of underinvestment for the sampled firms shows an average value of about 0.05 . This means listed manufacturing firms in Nigeria underinvest, on average, about $5 \%$ of their assets. The average value of 0.05 is lower than the result reported by (Wang et al. 2015) of 0.07 but higher than the average value of (Chen et al. 2011) of 4.3\% and the result reported by (Cherkasova and Rasadi 2017) of $1.6 \%$. The variation in the level of underinvestment shows that overall, underinvestment is more prevalent in emerging economies.

Table 3: Regression Result of the Impact of FCF on Investment Efficiency

\begin{tabular}{|c|c|c|c|}
\hline & Model 1 & Model 2 & Model 3 \\
\hline \multirow[t]{2}{*}{ Constant } & $0.094 * * *$ & $0.096 * * *$ & $0.059 * * *$ \\
\hline & $(0.002)$ & $(0.021)$ & $(0.020)$ \\
\hline \multirow[t]{2}{*}{ FCF } & $0.010^{* *}$ & $0.062^{* * *}$ & 0.178 \\
\hline & $(0.005)$ & $(0.018)$ & (0.144) \\
\hline \multirow[t]{2}{*}{ Grwth } & -0.001 & $-0.055^{*}$ & -0.011 \\
\hline & $(0.003)$ & $(0.021)$ & $(0.023)$ \\
\hline \multirow[t]{2}{*}{ Lev } & $-0.013 * * *$ & 0.023 & 0.087 \\
\hline & $(0.002)$ & (0.023) & $(0.106)$ \\
\hline \multirow[t]{2}{*}{ Cash } & $0.035^{* * *}$ & -0.038 & -0.129 \\
\hline & $(0.003)$ & (0.028) & (0.134) \\
\hline \multirow[t]{2}{*}{ Size } & $-0.006^{* * *}$ & & $-0.018^{* *}$ \\
\hline & $(0.0003)$ & & (0.008) \\
\hline \multirow[t]{2}{*}{ Ret } & $0.017 * * *$ & -0.008 & -0.024 \\
\hline & $(0.002)$ & $(0.011)$ & $(0.057)$ \\
\hline \multirow[t]{2}{*}{ Age } & $0.0002^{* * *}$ & $-0.001 * *$ & \\
\hline & $(0.0001)$ & $(0.0004)$ & \\
\hline \multirow[t]{2}{*}{ Tan } & $0.007 * *$ & -0.041 & 0.040 \\
\hline & $(0.004)$ & (0.028) & $(0.047)$ \\
\hline \multirow[t]{2}{*}{-Inv } & $0.068^{* *}$ & & $1.075^{* * *}$ \\
\hline & $(0.033)$ & & $(0.226)$ \\
\hline \multirow[t]{2}{*}{$\mathrm{CFO}$} & $0.013^{* * *}$ & 0.053 & 0.334 \\
\hline & $(0.004)$ & $(0.049)$ & $(0.252)$ \\
\hline \multirow[t]{2}{*}{ Slack } & 0.0001 & $0.093^{* *}$ & 0.074 \\
\hline & $(0.003)$ & $(0.041)$ & $(0.075)$ \\
\hline R-Sq. & 0.688 & 0.073 & 0.038 \\
\hline
\end{tabular}

Source: Computed by the Researcher using STATA16

$* * *, * *, *$ denote that the parameter estimates are statistical significant at $1 \%, 5 \%$ and $10 \%$ levels respectively. Standard errors in parentheses 
Model one in Table 3 presents the relationship results between the dependent variable (IE) and the explanatory variables, answering research hypothesis one. Looking at the individual variable contribution to the model, starting with the independent variable FCF, the OLS result reveals that FCF has a positive and strong relationship at a 5\% level of significance with IE of listed manufacturing firms in Nigeria. This implies that an increase in FCF leads to a proportionate increase in IE after controlling for all the other variables in the model. These findings support Ebrahimi Rad et al., (2016); Sheu \& Lee, (2012), who found that investment has a significantly positive relationship with FCF in China and Malaysia, respectively. This means that financially constraint firms may experience investment inefficiencies due to lack of cash since positive free cash is a significant determinant of investment efficiency in listed manufacturing firms in Nigeria.

For the control variables, the OLS regression outcomes reveal that cash, past stock returns, age and cash flow from operations are positively and statistically significant at a $1 \%$ level of significance with IE. This indicates that an increase in one of these control variables will have a proportionate increase in the level of investment efficiency. Similarly, tangibility and lagged investment have a positive and statistically significant relationship with IE at a 5\% significance level. This also indicates that these control variables are essential determinants of efficient investment; thus, an increase in one results in a corresponding increase in investment efficiency in Nigeria's listed manufacturing sector. Contrastingly, leverage and size have a negative and statistically significant relation with IE at a $1 \%$ significance level. This means that as leverage and size increase, investment efficiency reduces, thus having an inverse relationship. Many factors can lead to this inverse relationship, subsequently leading to inefficiencies in investment. Finally, growth has a negative but statistically insignificant relationship with IE, whereas slack has a positive but statistically insignificant relationship with IE. Since FCF is strongly significant in influencing IE, this provides the basis for rejecting the null hypothesis one of the studies.

Model 2 in Table 3 presents the results of the association between the dependent variable overinvestment and the independent variable FCF, as well as the control variables (growth, leverage, cash, return, age, tangibility, cash flow from operations and slack), thus providing the answer to research hypothesis two. From the Table, it is observed that the result reveal that FCF has a positive and statistically significant impact on overinvestment at a $1 \%$ level of significance of quoted manufacturing companies in Nigeria. This means that an increase in FCF level translates into a corresponding increase in the level of overinvestment. These findings confirm the agency theory as it relates to the use of FCF. The findings also support the overwhelming majority of previous studies such as Richardson (2006), Verdi (2006), Biddle et al. (2009), Ding et al. (2012), Wang et al. (2015), Guariglia \& Yang (2016), Chen et al. (2016), Filsaraei et al. (2016), Moez \& Amina (2018).

Similarly, slack has a positive and significant impact on overinvestment at a $1 \%$ level of significance. Hence, an increase in the ratio of cash to PPE leads to a resultant increase in overinvestment. Also, leverage and cash flow from operations have a positive but insignificant impact on overinvestment.

Conversely, growth and age have a negative and significant impact on overinvestment at 10\% and 5\% levels of significance, respectively. Thus, growth and age have an inverse relationship with overinvestment as per listed manufacturing firms in Nigeria. Likewise, cash, return and tangibility has a negative but insignificant impact on overinvestment, hence not able to cause much influence on overinvestment in the listed manufacturing firms in Nigeria. Since FCF is significant in influencing overinvestment, this then provides the basis for rejecting null hypothesis three of the study.

Model 3 in Table 3 presents the impact of the independent variable (FCF) and the control variables (growth, leverage, cash, size, return, tangibility, lagged investment, cash flow from operations and slack) on the dependent variable underinvestment. From the Table, it is observed that the regression model result reveal that FCF has a positive but statistically insignificant impact on overinvestment in the quoted manufacturing companies in Nigeria. This means that FCF does not increase nor reduce underinvestment in the sampled firms. 
The findings contradict the findings of Guariglia \& Yang (2016). Similarly, lagged investment has a positive and statistically significant impact on underinvestment at a $1 \%$ significance level. This means that lagged investment increases the sensitivity of underinvestment, thereby worsening the level of underinvestment among firms prone to underinvestment in the listed manufacturing firms in Nigeria.

On the contrary, size has a negatively and statistically significant impact on underinvestment. This shows that the larger the company's size, the lower its tendency to underinvest in the listed manufacturing sector in Nigeria. Similarly, growth, cash and return have a negative but statistically insignificant impact on underinvestment. On the opposite, leverage, tangibility, cash flow from operations and slack has a positive but statistically insignificant impact on underinvestment. Since FCF is not significant in influencing underinvestment, this then provides the basis for accepting null hypothesis three of the study.

\section{Conclusion}

This study shows the nature of the resources (FCF) available in the manufacturing sector and its constraints on investment efficiency in Nigeria. Two main conclusions emerge from this study: On the one hand, having a consistent positive free cash flow is a requirement for achieving optimal investment level in the listed manufacturing companies in Nigeria. On the other hand, managers with excess free cash might engage in wasteful expenditure since FCF is found to have a positive and significant impact on overinvestment, which confirms the agency theory of FCF. The identification of FCF as a significant determinant of investment efficiency implies that in order to attain an optimal level of investment, firms in the listed manufacturing sector in Nigeria should strive to maintain a positive FCF since FCF has a substantial impact on the level of expected investment. Consequently, listed manufacturing firms that are highly levered and cash-constrained may find it challenging to attain an optimal investment level. As such, managers should emphasize the facilitation of equity capital on the one hand, and on the other hand, policymakers should encourage manufacturing firms by reducing the cost of debt.

Similarly, information asymmetry and agency problems have been identified as explanations for overinvestment. Hence, to enhance investment efficiency in Nigeria, more attention should be given to the trend of accrualbased earnings that are not sustainable, especially those related to receivables', sales, and revenue of the sector. Also, investors should pay close attention to the accounts of listed manufacturing firms related to the maintenance of assets in place, such as depreciation, which can influence earnings to look better in the current period but detrimental to the firm in the long run.

However, this study is not without limitations. This work only examines the impact of FCF and on IE. Future studies can look at other aspects that influence investment, such as the impact of investment on financial reporting quality or the effect of debt holders on IE. Another limitation is that the findings of this study cannot be generalized to other countries, especially advanced countries, because of the peculiarities of emerging markets which are reasonably different from that of an advanced country.

Funding: "This research received no external funding."

Conflicts of Interest: "The authors declare no conflict of interest."

\section{References}

Angela, Windy, Aryancana Rilya, and Rilya Aryancana. 2017. "The Effect of Financial Reporting Quality on Financing and Investment." Etikonomi 16(1):81-92. doi: 10.15408/etk.v16i1.4600.

Bhundia, Amalendu. 2012. "A Comparative Study Between Free Cash Flows and Earnings Management." Business Intelligence Journal 5(1):123-29.

Biddle, Gary C., Giles Hilary, and Rodrigo S. Verdi. 2009. "How Does Financial Reporting Quality Relate to 
Investment Efficiency ?" Journal of Accounting and Economics 48(2-3):112-31. doi:

http://dx.doi.org/10.1016/j.jacceco.2009.09.001.

Biddle, Gary, and Giles Hilary. 2006. "Accounting Quality and Firm-Level Capital Investment." The Accounting Review 81(5):963-82.

Chen, Feng, Ole-kristian Kristian Hope, Qingyuan Li, and Xin Wang. 2011. "Financial Reporting Quality and Investment Efficiency of Private Firms in Emerging Markets." Accounting Review 86(4):1255-88. doi: $10.2308 /$ accr-10040.

Chen, Marco. 2017. "Investigating the Relationship between Firm Investment Sensitivity and Financing Constraints with a Distinctive Chinese Firm Data Set."

Chen, Xin, Yong Sun, and Xiaodong Xu. 2016. "Free Cash Flow, over-Investment and Corporate Governance in China." Pacific Basin Finance Journal 37(April 2016):81-103. doi: 10.1016/j.pacfin.2015.06.003.

Cherkasova, Victoria, and Daryush Rasadi. 2017. "Earnings Quality and Investment Efficiency: Evidence from Eastern Europe." Review of Economic Perspectives 17(4):441-68. doi: 10.1515/revecp-2017-0023.

Cherkasova, Victoria, and Evgeniya Zakharova. 2016. "Suboptimal Investments and M\&A Deals in Emerging Capital Markets." Econmic Annals LXI(208):93-120. doi: 10.2298/EKA1608093C.

Ding, Sai, Alessandra Guariglia, and John Knight. 2012. "Does China Overinvest? Evidence from Panel of Chinese Firms." Pp. 1-39 in China and the World Economy. Nottinggham: Leverhulme Centre.

Ebrahimi Rad, Seyed Sajad, Zaini Embong, Norman Mohd-Saleh, and Romlah Jaffar. 2016. "Financial Information Quality and Investment Efficiency: Evidence from Malaysia." Asian Academy of Management Journal of Accounting and Finance 12(1):129-51.

Fakhroni, Zaki, Ghozali Imam, Harto Puji, and Etna Yuyetta, Nur, Afri. 2018. "Free Cash Flow, Investment Inefficiency, and Earnings Management : Evidence from Manufacturing Firms Listed on the Indonesia Stock Exchange." Investment Management and Financial Innovations 15(1):299-310. doi: 10.21511/imfi.15(1).2018.25.

Filsaraei, Mahdi, Morteza Moradi, Javad Askari Zadeh, Masoumeh Bahadori, and Maryam Mohseni. 2016. "Investigating the Relationship between F Irm's Corporate Governance, Free Cash Flow and Overinvestment." Applied Mathematics in Engineering, Management and Technology 4(2):32-39.

Firth, Michael, Lingmin Xie, and Yuanyuan Zhang. 2016. How Do Analysts' Forecast Characteristics Relate to Investment Efficiency ? Hong Kong.

Gao, Ru, and Xin Yu. 2018. "How to Measure Capital Investment Efficiency: A Literature Synthesis." Accounting \& Finance (1998):1-36. doi: 10.1111/acfi.12343.

Guariglia, Alessandra, and Junhong Yang. 2016. "A Balancing Act: Managing Financial Constraints and Agency Costs to Minimize Investment Inefficiency in the Chinese Market." Journal of Corporate Finance 36(Feb 2016):111-30. doi: 10.1016/j.jcorpfin.2015.10.006.

Jafari, Halle. 2016. "Financial Reporting Quality , Debt Maturity Investment Efficiency." Bulletin de La Societe Des Sciences de Liege 85:1283-96.

Jensen, C., and H. Meckling. 1976. "Theory of the Firm : Managerial Behaviour, Agency Costs and Ownership Structure." Journal of Financial Economics 3:305-60.

Jensen, Michael C. 1986. "Agency Costs of Free Cash Flow, Corporate Finance, and Takeovers." American Economic Review 76(2):323-29. doi: 10.2139/ssrn.99580.

Ku, H. S. L., U. Mustapha, and S. Goh. 2010. "Literature Review of Past and Present Performance of the Nigerian Manufacturing Sector." Proceedings of the Institution of Mechanical Engineers, Part B: Journal of Engineering Manufacture 224(12):1894-1904. doi: 10.1243/09544054JEM1818.

Lai, Shu-miao, Chih-liang Liu, and Taychang Wang. 2013. "Increased Disclosure and Investment Efficiency." Asia-Pacific Journal of Accounting \& Economics 1-20. doi: 10.1080/16081625.2012.741791.

Li, Leye, Gary S. Monroe, and Jeff Coulton. 2018. Managerial Litigation Risk and Corporate Investment Efficiency: 
Evidence from Derivative Lawsuits. Sydney, Australia.

Majeed, Muhammad Ansar, Xianshi Zhang, and Umar Muhammad. 2017. "Impact of Investment Efficiency on Cost of Equity: Evidence from China." Journal of Asia Business Studies. doi: https://doi.org/10.1108/JABS-09-2015-0163.

Mcdermott, Katie E. 2012. "Financial Reporting Quality and Investment in Corporate Social Responsibility." University of North Carolina.

McNichols, Maureen F., and Stephen R. Stubben. 2008. "Does Earnings Management Affect Firms' Investment Decisions?" The Accounting Review 83(6):1571-1603. doi: 10.2308/accr.2008.83.6.1571.

Modigliani, Franco, and Merton H. Miller. 1958. "The Cost of Capital, Corporation Finance and the Theory of Investment." The American Economic Review 48(3):261-97.

Moez, EL Gaied, and Zgarni Amina. 2018. "Overinvestment of Free Cash Flow and Manager's Overconfidence." International Business Researcb 11(3):48. doi: 10.5539/ibr.v11n3p48.

Nekhili, Mehdi, Ines Fakhfakh Ben Amar, Tawhid Chtioui, and Faten Lakhal. 2016. "Free Cash Flow and Earnings Management: The Moderating Role of Governance and Ownership." Journal of Applied Business Research 32(1):255-68. doi: 10.19030/jabr.v32i1.9536.

Nekhili, Mehdi, Ines Fakhfakh, Ben Amar, Tawhid Chtioui, and Faten Lakhal. 2016. "Free Cash Flow And Earnings Management: The Moderating Role of Governance And Ownership." The Journal of Applied Business Research 32(1):255-68.

Ogunleye, E. O., P. A. Adeyemi, G. T. Asamu, and Ado- Ekiti. 2018. "The Size, Growth and Profitability of Quoted Manufacturing Companies in Nigeria : Panel Data Analysis." 45:1-7.

Rad, S. S. E., Zaini Embong, Norman Mohd-Saleh, and Romlah Jaffar. 2016. "Financial Information Quality and Investment Efficiency: Evidence from Malaysia." Asian Academy of Management Journal of Accounting and Finance 12(1):129-51.

Richardson, Scott. 2006. "Over-Investment of Free Cash Flow." Review of Accounting Studies 11(2-3):159-89. doi: 10.1007/s11142-006-9012-1.

Sheu, Her Jiun, and Shiou Ying Lee. 2012. "Excess Cash Holdings and Investment: The Moderating Roles of Financial Constraints and Managerial Entrenchment." Accounting and Finance 52(SUPPL.1):287-310. doi: 10.1111/j.1467-629X.2012.00500.x.

Soderbom, Mans, and Francis Teal. 2002. "The Performance of Nigerian Manufacturing Firms: Report on the Nigerian Manufacturing Enterprise Survey 2006." UNITED NATIONS INDUSTRIAL DEVELOPMENT ORGANIZATION NIGERIAN FEDERAL MINISTRY OF INDUSTRY CENTRE FOR THE STUDY OF AFRICAN ECONOMIES Department of Economics, University of Oxford (May 2014):69.

Umoru, David, and Gladys A. Nwokoye. 2018. "FAVAR Analysis of Foreign Investment with Capital Market Predictors: Evidence on Nigerian and Selected African Stock Exchanges." Academic Journal of Economic Studies 4(1):12-20.

Verdi, Rodrigo S. 2006. "Financial Reporting Quality and Investment Efficiency." University of Pennsylvania. Wang, Fusheng, Zhibiao Zhu, and John Hoffmire. 2015. "Financial Reporting Quality, Free Cash Flow, and Investment Efficiency." SHS Web of Conferences 17:01027. doi: 10.1051/shsconf/20151701027. 